\title{
Research Article \\ Effect of Selected Metal Contaminants on the Stability of Castor Oil Methyl Ester
}

\author{
Christopher E. Akhabue, John C. Iworah, and Felix A. Aisien \\ Department of Chemical Engineering, Faculty of Engineering, University of Benin, Benin City 300001, Nigeria \\ Correspondence should be addressed to Christopher E. Akhabue; chrisakhabue@uniben.edu
}

Received 28 June 2013; Accepted 6 November 2013; Published 28 January 2014

Academic Editors: X. Lu, T. M. I. Mahlia, and S. Som

Copyright (C) 2014 Christopher E. Akhabue et al. This is an open access article distributed under the Creative Commons Attribution License, which permits unrestricted use, distribution, and reproduction in any medium, provided the original work is properly cited.

\begin{abstract}
This study investigates the effect of iron ( $\mathrm{Fe})$ and aluminium $(\mathrm{Al})$ contaminants on the stability of castor oil methyl ester (COME). COME was synthesized via transesterification reaction and the peroxide value of the COME was used to monitor its stability. Varied amounts of $\mathrm{Fe}$ and $\mathrm{Al}(0.2 \mathrm{~g}, 0.4 \mathrm{~g}, 0.6 \mathrm{~g}, 0.8 \mathrm{~g}$, and $1.0 \mathrm{~g})$ in powdered form were added to $100 \mathrm{~mL}$ of COME and their effect on the peroxide value was monitored for a day, for the first phase of the experiment, while for the second phase, $0.3 \mathrm{~g}$ and $0.8 \mathrm{~g}$ of these metals were added to $100 \mathrm{~mL}$ COME, and their effect was monitored for 9 days. At the end of the study, it was observed that as the amount of the metals added to the COME increases from 0.2 to $1.0 \mathrm{~g} / 100 \mathrm{~mL}$ COME, the peroxide values of the COME decrease from 1.6 to $0.3 \mathrm{meq} / \mathrm{kg}$ and 1.2 to $0.3-0.2 \mathrm{meq} / \mathrm{kg}$ for $\mathrm{Al}$ and $\mathrm{Fe}$ contaminated COME after $24 \mathrm{~h}$. Also in the second phase of the experiment, the peroxide value of the $0.3 \mathrm{~g}$ Fe metal contaminated COME increased from 1.4 to $11.6 \mathrm{meq} / \mathrm{kg}$ while that of $0.8 \mathrm{~g}$ Fe contaminated COME increased from 1.4 to $3.0 \mathrm{meq} / \mathrm{kg}$ after the nine-day period of investigation.
\end{abstract}

\section{Introduction}

Biodiesel also known as fatty acid alkyl esters (FAAE) is an alternative fuel, derived from vegetable oils, animal fats, or waste cooking oils through transesterification of triglycerides with an alcohol in the presence of a catalyst [1-5]. In recent years, researches on biodiesel have attracted a considerable amount of attention because of its renewability and its several advantages over the conventional petroleum diesel. These advantages include nontoxicity, biodegradability, and the reduction in vehicle emissions such as carbon monoxide and particulate matters [6]. The use of vegetable oil derivatives as direct replacements for diesel fuel is not only environmentally advantageous but is also rapidly becoming an economically viable strategy for sourcing part of the global fuel oil requirements. The use of edible vegetable oils for biodiesel production has not been successful in some parts of the world because of its unstable price [7]. As the demand for vegetable oils for food has increased substantially in recent years, it has become necessary to use nonedible oils for biodiesel production. Castor oil has been identified as an important nonedible source for the production of biodiesel $[5,8]$. Castor crops, from which castor oil is obtained, require relatively fewer inputs such as water, fertilizers, and pesticides. These crops can be grown on marginal land, thus providing an excellent opportunity for many regions of the world to utilize their land resources more effectively.

The properties of biodiesel depend on the composition of the feedstock for production. If the feedstock is composed of high amounts of unsaturated fatty acids, the oxidation stability of the resulting biodiesel is low [6-11]. Biodiesel instability results in the degradation of the fuel which alters the fuel properties and forms undesirable products. Such products include peroxides and gums; it also leads to an increase in the viscosity, increase in acid value of the fuel, a slight reduction in the heating value, and also an increase in the cetane number. Biodiesel, when exposed to air or oxygen, results in the formation of alcohols which are further oxidized to acids [11]. The presence of alcohol will lead to a reduction in the flash point, and also an increase in the total acid number results in the corrosion of the fuel line $[3,5,10]$. The sensitivity of biodiesel to oxidation is due to the unsaturated fatty acid content in the oil [12]. Other factors which also have an influence on the oxidation stability of biodiesel are 
light, temperature, presence of metal contaminants, nature of storage containers, and the presence of antioxidants $[6,7,11$, 12].

The chemistry of oxidation is based on the primary and secondary oxidation processes $[13,14]$. The primary oxidation processes involve the production of low molecular weight compounds such as hydroperoxides in the fuel. The secondary oxidation process on the other hand results in the formation of higher molecular weight species that leads to an increase in viscosity and solid deposits.

The mechanism for the primary oxidation processes of biodiesel can be divided into three stages, namely, initiation, propagation, and the termination stages [6].

Initiation Stage. The initiation stage as shown in (1) involves the removal of hydrogen from the carbon atom of the biodiesel $(\mathrm{RH})$ by an initiator radical $\left(\mathrm{I}^{\circ}\right)$ to form a carbonbased fatty acid radical $\left(\mathrm{R}^{\mathrm{O}}\right)$ :

$$
\mathrm{RH}+\mathrm{I}^{\mathrm{o}} \longrightarrow \mathrm{R}^{\mathrm{o}}+\mathrm{IH}
$$

These initiator radicals are formed by different mechanisms including

(i) thermal dissociation of hydroperoxides $(\mathrm{ROOH})$ that are present as impurities:

$$
\mathrm{ROOH} \longrightarrow \mathrm{RO}^{\circ}+\mathrm{OH}^{\mathrm{O}}
$$

(ii) metal (M) catalyzed decomposition of hydroperoxides:

$$
\begin{aligned}
& \mathrm{ROOH}+\mathrm{M}^{2+} \longrightarrow \mathrm{RO}^{\mathrm{o}}+\mathrm{OH}^{\mathrm{o}}+\mathrm{M}^{3+} \\
& \mathrm{ROOH}+\mathrm{M}^{3+} \longrightarrow \mathrm{ROO}^{\mathrm{o}}+\mathrm{H}^{+}+\mathrm{M}^{2+}
\end{aligned}
$$

(iii) photooxidation: this is the increase rate of oxidation of biodiesel exposed to light.

Propagation Stage. During the propagation stage, the carbon free radical $\mathrm{R}^{\circ}$ formed at the initiation stage is very reactive and it easily combines with a biradical oxygen in the air resulting in the formation of peroxyl radical, $\mathrm{ROO}^{\circ}$. This peroxyl radical abstracts a hydrogen atom from a biodiesel molecule to form another carbon-free radical and a hydroperoxide:

$$
\begin{gathered}
\mathrm{R}^{\mathrm{o}}+\mathrm{O}_{2} \longrightarrow \mathrm{ROO}^{\mathrm{o}} \\
\mathrm{ROO}^{\mathrm{o}}+\mathrm{RH} \longrightarrow \mathrm{ROOH}+\mathrm{R}^{\mathrm{o}}
\end{gathered}
$$

During this stage, up to 100 new radicals are created from one single radical, meaning that the decomposition occurs at an exponential rate and results in the formation of byproducts [15].

Termination Stage. The propagation process continues until two radicals combined together to form a stable product as shown in

$$
\begin{gathered}
\mathrm{R}^{\mathrm{o}}+\mathrm{R}^{\mathrm{o}} \longrightarrow \mathrm{R}-\mathrm{R} \\
\mathrm{ROO}^{\circ}+\mathrm{R}^{\mathrm{o}} \longrightarrow \mathrm{ROOR}
\end{gathered}
$$

The secondary oxidation process results in the formation of acids, esters, aldehydes, ketones, and so forth [16-19]. This leads to changes in the biodiesel properties, such as viscosity, acid number, and oxidation stability $[9,16,20,21]$. The stability of biodiesel can be improved by adding an appropriate antioxidant $[6,19,22]$. Commercial antioxidants, such as pyrogallol (PY), propyl gallate (PG), catechol, nordihydroguaiaretic acid, butylhydroxyanisole (BHA), butylhydroytoluene (BHT), and tert-butylhydroquinone (TBHQ), are usually added to biodiesel to enhance its stability $[9,19$, $20,22]$.

Biodiesel is stored in metallic and nonmetallic containers. These containers, especially the metallic containers, are prone to corrosion in the presence of biodiesel [21-23]. The adverse effects of the presence of metal contaminants on biodiesel stability have been reported in terms of the induction periods [23-25]. No attempt has been made to study the effect of these metal contaminants on the primary oxidation products of biodiesel.

The objective of this study, therefore, is to investigate the stability of castor oil methyl ester in the presence of aluminium and iron contaminants.

\section{Materials and Methods}

Castor oil was purchased from Stanvac Laboratory, Benin City, Edo State. All the reagents used, methanol, potassium hydroxide, glacial acetic acid, chloroform, potassium iodide, starch indicator, and $0.1 \mathrm{~N}$ sodium thiosulphate solution, were of analytical grade and were obtained from Onitsha Head Bridge Market, Anambra State, Nigeria. Iron and aluminium particles in powdered form $(5 \mu \mathrm{m})$ were obtained from the Mechanical Engineering Laboratory of the University of Benin, Benin City.

2.1. Castor Oil Methyl Ester Synthesis. Castor oil methyl ester (COME) was synthesized by reaction of methanol $(200 \mathrm{~mL})$ with castor oil $(1000 \mathrm{~mL})$ in the presence of $\mathrm{KOH}(1 \mathrm{wt} . \%$ of oil) in a hot magnetic plate stirrer for one hour. After completion of reaction, the material was transferred to a separating funnel and both the ester (biodiesel) and glycerin phases were separated. The upper phase was biodiesel and lower part was glycerin. The upper biodiesel phase was washed with warm water to remove traces of glycerin, unreacted catalyst, and soap formed during the transesterification reaction. The $\mathrm{pH}$ of the washing water was initially high at 10.4 due to dissolved $\mathrm{KOCH}_{3}$. After three successive washings, it reduces to about 7.8. The washing was continued until a $\mathrm{pH}$ of 7.1 was achieved. Finally, the biodiesel was heated to remove any traces of water that might still be present in it.

2.2. Physicochemical Analysis. Physicochemical analysis was carried out on the castor seed oil (CSO) and the COME according to the American (ASTM D 6751) standards. Analysis was done in triplicate and recorded as mean value \pm standard deviation. 
TABLE 1: Physicochemical properties of castor oil and castor oil methyl ester.

\begin{tabular}{lcccc}
\hline Properties & CSO & COME & $\begin{array}{c}\text { Biodiesel standard } \\
\text { ASTM D6751 }\end{array}$ & Test method \\
\hline Specific gravity & $1.562 \pm 0.34$ & $0.893 \pm 0.18$ & $0.87-0.90$ & ASTM D4502 \\
Acid value $(\mathrm{mg} \mathrm{KOH} / \mathrm{g}$ oil) & $1.60 \pm 0.25$ & $0.34 \pm 0.21$ & 0.80 max. & ASTM D664 \\
Iodine value $\left(\mathrm{mg} \mathrm{I}_{2} / 100 \mathrm{~g}\right.$ oil) & $121.40 \pm 8.3$ & $95.0 \pm 6.2$ & 120 max. & D-664-11 \\
Peroxide value $(\mathrm{meq} / \mathrm{kg})$ & $8.80 \pm 0.56$ & $1.4 \pm 0.28$ & - & EN 14111 \\
Cloud point $\left({ }^{\circ} \mathrm{C}\right)$ & $\mathrm{n} / \mathrm{d}$ & $-5 \pm 1$ & 130.0 min. & ASTM D2500 \\
Flash point $\left({ }^{\circ} \mathrm{C}\right)$ & $230 \pm 4$ & $190 \pm 5$ & $1.9-6.0$ & ASTM D93 \\
Viscosity $\left(40^{\circ} \mathrm{C}\right)\left(\mathrm{mm}^{2} / \mathrm{s}\right)$ & $214 \pm 10.8$ & $6.0 \pm 2.3$ & 47 min. & ASTM D445 \\
Cetane number & $\mathrm{n} / \mathrm{d}$ & 51.6 & & ASTM D613 \\
\hline
\end{tabular}

${ }^{*}$ n/d: not determined.

2.3. Sample Preparation. The effect of the two metal contaminants on the peroxide values of COME was carried out by adding varied amounts of $\mathrm{Al}$ and $\mathrm{Fe}$ particles to $100 \mathrm{~mL}$ of COME. In the first phase of the study, varied amounts $(0.2$, $0.4,0.6,0.8$, and $1.0 \mathrm{~g}$ ) of $\mathrm{Al}$ and $\mathrm{Fe}$ as contaminants were added to $100 \mathrm{~mL}$ COME and their effect on the peroxide value was monitored after $24 \mathrm{~h}$. In the second phase of the study, $0.3 \mathrm{~g}$ and $0.8 \mathrm{~g}$ of both $\mathrm{Al}$ and $\mathrm{Fe}$ were added to $100 \mathrm{~mL} \mathrm{COME}$ and their effect on the peroxide values of the contaminated COME was monitored for nine days.

2.4. Peroxide Value Determination. The peroxide value of the biodiesel samples was measured by titrating with sodium thiosulfate according to AOAC standards [26]. Briefly, $2 \mathrm{~g}$ of the biodiesel sample was weighed and $10 \mathrm{~mL}$ chloroform was added in a stoppered conical flask. $15 \mathrm{~mL}$ acetic acid and $1 \mathrm{~mL}$ potassium iodide $10 \%$ were added. The flask was shaken for $2 \mathrm{~min}$ and left in the dark for $5 \mathrm{~min}$. Then, $75 \mathrm{~mL}$ of deionized water was added and titration was done with solution of sodium thiosulfate $0.01 \mathrm{~N}$ and $1 \%$ starch solution as indicator. A blank run was also carried out. The peroxide value expressed as meq $/ \mathrm{kg}$ of biodiesel sample was calculated by the following formula:

$$
\text { peroxide value }(\mathrm{meq} / \mathrm{kg})=\frac{\left[\left(V-V_{0}\right) \times C \times 1000\right]}{W},
$$

where $V$ is the volume $(\mathrm{mL})$ of sodium thiosulfate solution for the biodiesel sample, $V_{0}$ is the volume $(\mathrm{mL})$ of sodium thiosulfate solution for the blank, $C$ is the molar concentration of sodium thiosulfate solution, and $W$ is the biodiesel sample weight $(\mathrm{g})$.

\section{Results and Discussion}

3.1. Physicochemical Properties of Castor Oil and Biodiesel Samples. The results in Table 1 show a comparison of the physicochemical properties of the castor seed oil (CSO) and the castor oil methyl ester (COME). The CSO has a specific gravity of 1.56 which reduced to 0.89 after transesterification reaction to produce the COME. The value for COME, however, falls within the range of values as specified by the ASTM D6751 standard. The iodine value (IV) of the castor oil was $121.40 \mathrm{mg} \mathrm{I}_{2} / \mathrm{g}$ oil. This could be attributed to its high content of unsaturated fatty acids. This value was higher than values obtained in previous studies carried out on castor oil $[27,28]$. Akpan et al. [27] in their work got an iodine value of $87.72 \mathrm{mg} \mathrm{I}_{2} / \mathrm{g}$ oil for crude castor oil which was later reduced to $84.8 \mathrm{mg} \mathrm{I}_{2} / \mathrm{g}$ oil on modification by means of sulphation process. However, after the transesterification reaction, the iodine value for the resulting COME was found to be $95.0 \mathrm{mg} \mathrm{I}_{2} / \mathrm{g}$ oil.

The cloud point of the COME was $-5^{\circ} \mathrm{C}$. This is the temperature at which wax first becomes visible as the temperature was lowered. This value was much higher than that obtained by Berman et al. [29] and Ramezani et al. [30], but the value obtained was within the ASTM D6751 standard. The viscosity obtained for the $\mathrm{CSO}$ was $230 \mathrm{~mm}^{2} / \mathrm{s}$. As reported by Scholz and da Silva [31], the viscosities for castor seed oils range from 240 to $300 \mathrm{~mm}^{2} / \mathrm{s}$. It was however observed that there was a sharp decrease in the viscosity after the transesterification reaction to COME. This viscosity for the COME was $6.0 \mathrm{~mm}^{2} / \mathrm{s}$, which is within the biodiesel range of $1.9-6.0 \mathrm{~mm}^{2} / \mathrm{s}$.

The cetane number, which is a measure of the ignition quality of diesel fuels and one of the prime indicators of the quality of diesel, was calculated to be 51.60. Although the value fell within the limits of ASTM D6751 standard, this value was a little higher than values obtained by Berman et al. [29] and Sreenivas et al. [28] which were 48.9 and 42 , respectively. The flash point of the $\mathrm{CSO}$ was measured to be $230^{\circ} \mathrm{C}$ which reduced to $190^{\circ} \mathrm{C}$ after the transesterification reaction to COME. The flash point is the lowest temperature at which the fuel ignites when exposed to a heat source. The flash point value obtained for the COME falls within that specified by the ASTM D6751, which should be a minimum flash point value of $130^{\circ} \mathrm{C}$ for biodiesel.

3.2. Effect of Metal Contaminants on the Peroxide Value (PV) of Castor Oil Methyl Ester. Figure 1 shows the amount of peroxides formed in the COME containing varied amounts of metal contaminants after a $24 \mathrm{~h}$ period. The result shows that as the amount of metal contaminants increases, the peroxide values of the COME decrease. The formation of peroxides in the Fe contaminated COME was more pronounced compared to that contaminated with $\mathrm{Al}$. In previous studies carried out, the presence of metal contaminants has been found to 




FIGURE 1: Effect of metal contaminants on the oxidation stability of castor oil methyl ester after a $24 \mathrm{~h}$ period.

reduce the induction period of biodiesel $[32,33]$. For the Fe contaminated COME, the peroxide values reduced from 1.6 to $0.3 \mathrm{meq} / \mathrm{kg}$ COME as the amount of contaminants increases from 0.2 to $1 \mathrm{~g} / 100 \mathrm{~mL}$ COME. Similarly, the peroxide values for the $\mathrm{Al}$ contaminated biodiesel reduce from 1.2 to $0.2 \mathrm{meq} / \mathrm{kg}$ COME as the amount of $\mathrm{Al}$ contaminants increases from 0.2 to $1.0 \mathrm{~g} / 100 \mathrm{~mL}$. This indicates that the more the metal contaminants, the more the decrease in peroxide values of the COME. This result confirmed that the presence of metal contaminants leads to decomposition of hydroperoxides [6].

The effect of varying concentrations of $\mathrm{Fe}$ and $\mathrm{Al}$ contaminants on the peroxide values of COME as monitored for nine days is shown in Figure 2. The peroxide values for both the contaminated and uncontaminated COME steadily increase with time during the first four days of our investigation. COME without metal contaminants experiences the greatest increase from 1.4 to $5.8 \mathrm{meq} / \mathrm{kg}$ COME, followed by $0.3 \mathrm{~g} \mathrm{Fe} / 100 \mathrm{~mL}$ COME, $0.3 \mathrm{~g} \mathrm{Al} / 100 \mathrm{~mL}$ COME, $0.8 \mathrm{~g} \mathrm{Al} / 100 \mathrm{~mL}$ COME, and $0.8 \mathrm{~g} \mathrm{Fe} / 100 \mathrm{~mL}$ COME in that order. The peroxide value of the uncontaminated COME is observed to be higher than the contaminated COME samples containing varying amounts of contaminants for the first four days. This was in line with the first phase of the experiment where it was discovered that the presence of metal contaminants reduces the amount of peroxides formation in the COME.

It was also observed that, as time in days elapses from the fifth day, the peroxide value of the contaminated COME containing $0.3 \mathrm{~g} \mathrm{Fe} / 100 \mathrm{~mL}$ COME was higher than that of the uncontaminated COME while that of the $0.3 \mathrm{~g} \mathrm{Al} / 100 \mathrm{~mL}$ was observed to be rising significantly but lower than that of the uncontaminated COME. However, there was a steady increase in the peroxide value for the $0.3 \mathrm{~g} \mathrm{Al} / 100 \mathrm{~mL}$ COME between the sixth and the ninth day as compared to that

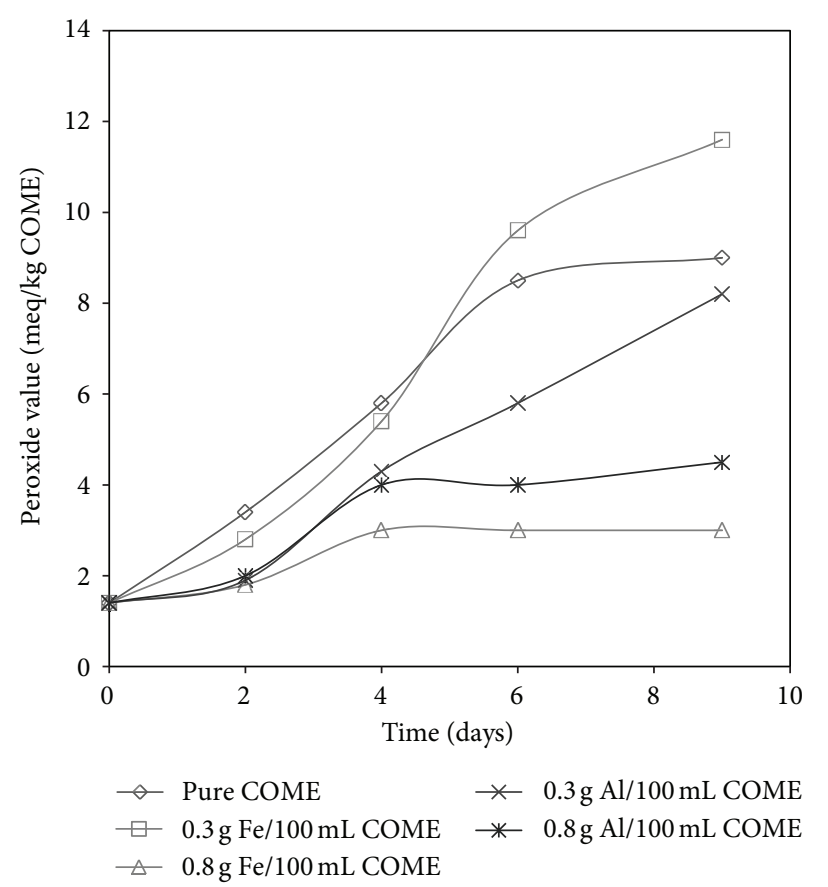

FIGURE 2: Effect of different concentrations of metal contaminants on the peroxide value of COME.

of the uncontaminated COME which had almost assume a constant peroxide value during this period. Thus, the presence of these metal contaminants in small amounts $(0.3 \mathrm{~g} / 100 \mathrm{~mL}$ COME) can be said to enhance the formation of hydroperoxides. Although the COME contaminated with $0.3 \mathrm{~g}$ Fe had a stronger catalytic effect when compared to the COME contaminated with $0.3 \mathrm{~g} \mathrm{Al}$, both had strong positive influence on enhancing the formation of hydroperoxides as measured by their peroxide values.

The COME contaminated with $0.8 \mathrm{~g}$ Fe and $\mathrm{Al}$ was characterized by a slight increase in the peroxide values for the first four days, after which they both assume a constant value of 3.0 and $4.0 \mathrm{meq} / \mathrm{kg}$ COME for $\mathrm{Fe}$ and $\mathrm{Al}$ contaminated COME, respectively. In comparison with the COME in which $0.3 \mathrm{~g} \mathrm{Fe}$ and $\mathrm{Al}$ were added, the peroxide values for COME contaminated with $0.8 \mathrm{~g} F$ and $\mathrm{Al}$ were lower.

The findings from this study reveal that, in the presence of small amount of metal contaminants, more hydroperoxides are produced as compared to when large amounts of metal contaminants are present. In this case, the presence of metals in the COME resulted in decomposition of hydroperoxides $[6,20]$. This can be explained by the fact that the primary oxidation process is gradually tending towards the secondary oxidation process, where other oxidation products like aldehydes, alcohols, and shorter-chain carboxylic acids are being formed from the decomposition of the peroxides.

\section{Conclusions}

The stability of the COME is reduced in the presence of metals. Of the two metals investigated, Fe appears to have 
a stronger detrimental and catalytic effect on stability than Al. Under short-term storage durations, for example, a day, the peroxide value of the COME was found to decrease as the concentration of metal contaminants increases. For longer period of days, it was observed that the increases in peroxide values in the COME contaminated with small amounts of metal contaminants are much higher than those in COME contaminated with large amounts of COME. From the study, it was observed that when metal contaminants are increased, the rate of hydroperoxide decomposition to other products is more than the rate of hydroperoxide formation. It can be concluded that, in the presence of large amounts of metal contaminants, the primary stage of oxidation is reduced leading to the formation of secondary oxidation products such as carboxylic acids and aldehydes.

\section{Conflict of Interests}

The authors declare that there is no conflict of interests regarding the publication of this paper.

\section{References}

[1] K. Faupel and A. Kurki, "Biodiesel: A Brief Overview," 2011, http://www.attra.ncat.org/attra-pub/biodiesel.html.

[2] A. Monyem and J. H. Van Gerpen, "The effect of biodiesel oxidation on engine performance and emissions," Biomass and Bioenergy, vol. 20, no. 4, pp. 317-325, 2001.

[3] M. Pugazhvadivu and S. Rajagopan, "Investigation on a diesel engine fuelled with biodiesel blends and diethyl as an additive," India Journal of Science and Technology, vol. 2, no. 5, pp. 31-35, 2009.

[4] J. P. Szybist, A. L. Boehman, J. D. Taylor, and R. L. McCormick, "Evaluation of formulation strategies to eliminate the biodiesel NO x effect," Fuel Processing Technology, vol. 86, no. 10, pp. 11091126, 2005.

[5] T. R. Venkateswara, G. R. Prabhakar, and C. R. Hema, "Experimental investigation of pongamia, jatropha and neem methyl esters as biodiesl on C.I. engine," Jordan Journal of Mechanical and Industrial Engineerin, vol. 2, pp. 117-122, 2008.

[6] J. Pullen and K. Saeed, "An overview of biodiesel oxidative stability," Renewable and Sustain-Able Energy Reviews, vol. 16, pp. 5924-5950, 2012.

[7] G. Knothe, "Some aspects of biodiesel oxidative stability," Fuel Processing Technology, vol. 88, no. 7, pp. 669-677, 2007.

[8] L. Canoira, J. García Galeán, R. Alcántara, M. Lapuerta, and R. García-Contreras, "Fatty acid methyl esters (FAMEs) from castor oil: production process assessment and synergistic effects in its properties," Renewable Energy, vol. 35, no. 1, pp. 208-217, 2010.

[9] A. K. Domingos, E. B. Saad, W. W. D. Vechiatto, H. M. Wilhelm, and L. P. Ramos, "The influence of BHA, BHT and TBHQ on the oxidation stability of soybean oil ethyl esters (biodiesel)," Journal of the Brazilian Chemical Society, vol. 18, no. 2, pp. 416423, 2007.

[10] R. Sarin, M. Sharma, S. Sinharay, and R. K. Malhotra, "JatrophaPalm biodiesel blends: an optimum mix for Asia," Fuel, vol. 86, no. 10-11, pp. 1365-1371, 2007.

[11] A. B. Chhetri, M. S. Tango, S. M. Budge, K. C. Watts, and M. R. Islam, "Non-edible plant oils as new sources for biodiesel production," International Journal of Molecular Sciences, vol. 9, no. 2, pp. 169-180, 2008.

[12] R. L. McCormick, M. Ratcliff, L. Moens, and R. Lawrence, "Several factors affecting the stability of biodiesel in standard accelerated tests," Fuel Processing Technology, vol. 88, no. 7, pp. 651-657, 2007.

[13] S. Jain and M. P. Sharma, "Stability of biodiesel and its blends: a review," Renewable and Sustainable Energy Reviews, vol. 14, no. 2, pp. 667-678, 2010.

[14] C. D. Bannister, C. J. Chuck, M. Bounds, and J. G. Hawley, "Oxidative stability of biodiesel fuel," Proceedings of the Institution of Mechanical Engineers D, vol. 225, no. 1, pp. 99-114, 2011.

[15] G. El Diwani, S. El Rafie, and S. Hawash, "Protection of biodiesel and oil from degradation by natural antioxidants of Egyptian Jatropha," International Journal of Environmental Science and Technology, vol. 6, no. 3, pp. 369-378, 2009.

[16] P. Bondioli, A. Gasparoli, L. Della Bella, S. Tagliabue, and G. Toso, "Biodiesel stability under commercial storage conditions over one year," European Journal of Lipid Science and Technology, vol. 105, no. 12, pp. 735-741, 2003.

[17] J. Hancsók, M. Bubálik, Á. Beck, and J. Baladincz, "Development of multifunctional additives based on vegetable oils for high quality diesel and biodiesel," Chemical Engineering Research and Design, vol. 86, no. 7, pp. 793-799, 2008.

[18] G. Karavalakis, D. Karonis, and S. Stournas, "Evaluation of the oxidation stability of diesel/biodiesel blends using the modified rancimat method," SAE International Journal of Fuels and Lubricants, vol. 2, no. 1, pp. 839-849, 2009.

[19] X. Chen and D. U. Ahn, "Antioxidant activities of six natural phenolics against lipid oxidation induced by $\mathrm{Fe}^{2+}$ or ultraviolet light," Journal of the American Oil Chemists' Society, vol. 75, no. 12, pp. 1717-1721, 1998.

[20] G. S. Dodos, F. Zannikos, and S. Stournas, "Effect of metals in the oxidation stability and lu-bricity of biodiesel fuel," SAE Technical Paper 2009-01-1829, 2009.

[21] Z. Ghazali, W. B. Wan Nik, K. H. Ku Bulat, F. N. Ani, and L. F. Xian, "The effect of light on the oxidative stability of palm olein," in Proceedings of the 1st International Conference on Natural Resources Engineering and Technology, pp. 631-637, Putrajaya, Malaysia, 2006.

[22] Y.-H. Chen, J.-H. Chen, Y.-M. Luo et al., "Property modification of jatropha oil biodiesel by blending with other biodiesels or adding antioxidants," Energy, vol. 36, no. 7, pp. 4415-4421, 2011.

[23] W. Wang, P. E. Jenkins, and Z. Ren, "Heterogeneous corrosion behaviour of carbon steel in water contaminated biodiesel," Corrosion Science, vol. 53, no. 2, pp. 845-849, 2011.

[24] M. A. Fazal, A. S. M. A. Haseeb, and H. H. Masjuki, "Effect of different corrosion inhibitors on the corrosion of cast iron in palm biodiesel," Fuel Processing Technology, vol. 92, no. 11, pp. 2154-2159, 2011.

[25] L. Díaz-Ballote, J. F. López-Sansores, L. Maldonado-López, and L. F. Garfias-Mesias, "Corrosion behavior of aluminum exposed to a biodiesel," Electrochemistry Communications, vol. 11, no. 1, pp. 41-44, 2009.

[26] "AOAC Official Method 965.33, Peroxide value of oils and fats," 2002.

[27] U. G. Akpan, A. Jimoh, and A. D. Mohammed, "Extraction, characterization and modification of castor seed oil," Leonardo Journal of Science, vol. 8, pp. 43-52, 2006.

[28] P. Sreenivas, V. R. Manilla, and K. C. Sekhar, "Development of biodiesel from castor oil," International Journal of Energy Science, vol. 1, no. 3, pp. 192-197, 2011. 
[29] P. Berman, S. Nizri, and Z. Wiesman, "Castor oil biodiesel and its blends as alternative fuel," Biomass and Bioenergy, vol. 35, no. 7, pp. 2861-2866, 2011.

[30] K. Ramezani, S. Rowshanzamir, and M. H. Eikani, "Castor oil transesterification reaction: a kinetic study and optimization of parameters," Energy, vol. 35, no. 10, pp. 4142-4148, 2010.

[31] V. Scholz and J. N. da Silva, "Prospects and risks of the use of castor oil as a fuel," Biomass and Bioenergy, vol. 32, no. 2, pp. 95-100, 2008.

[32] A. Sarin, R. Arora, N. P. Singh, M. Sharma, and R. K. Malhotra, "Influence of metal contaminants on oxidation stability of Jatropha biodiesel," Energy, vol. 34, no. 9, pp. 1271-1275, 2009.

[33] S.Jain and M. P. Sharma, "Effect of metal contaminants and antioxidants on the storage sta-bility of jatropha curcas biodiesel," Fuel, vol. 109, pp. 379-383, 2013. 


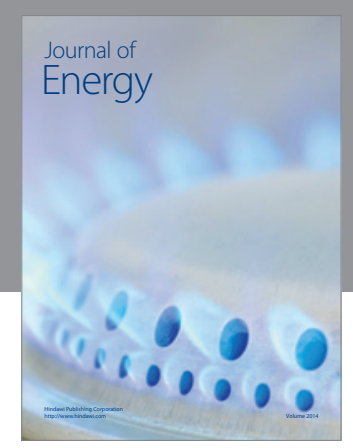

Journal of

Industrial Engineering
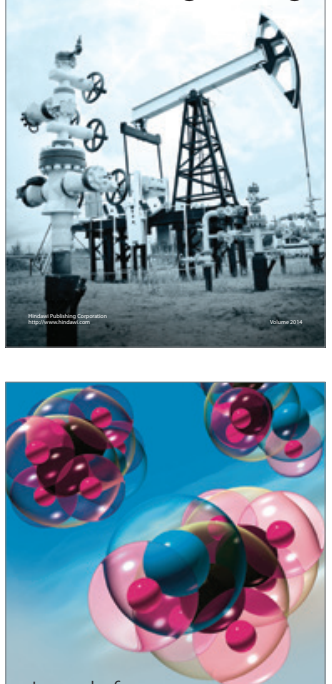

Fuels
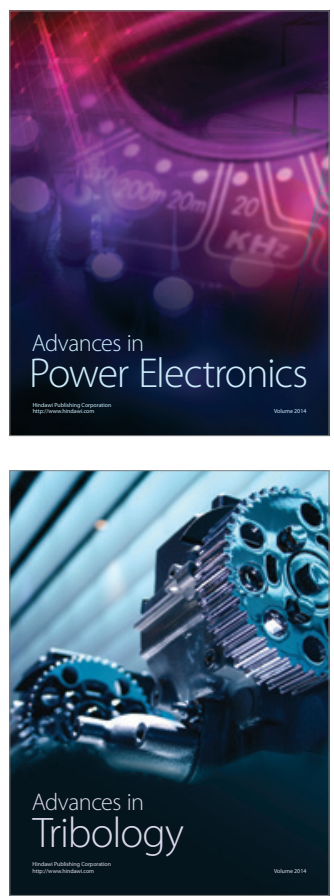

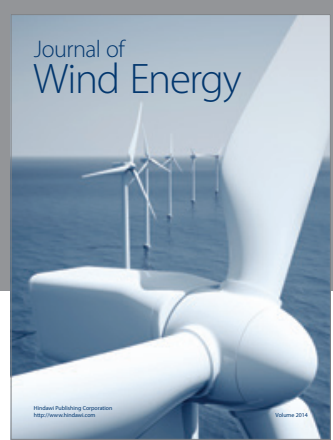

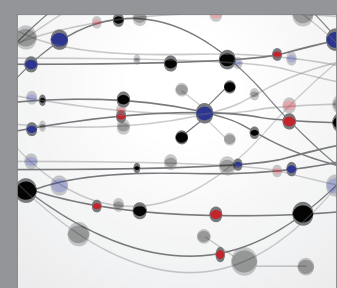

The Scientific World Journal

Submit your manuscripts at http://www.hindawi.com

Journal of

Structures
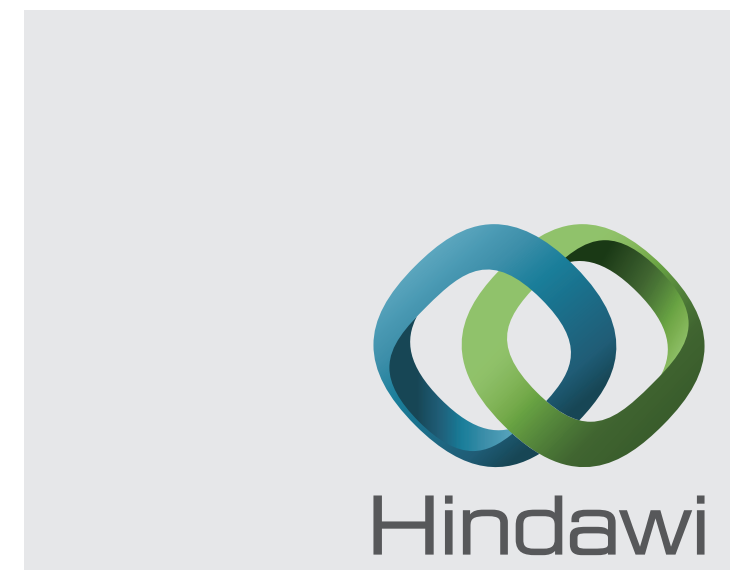

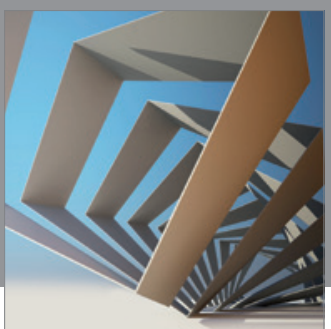

Rotating

Machinery
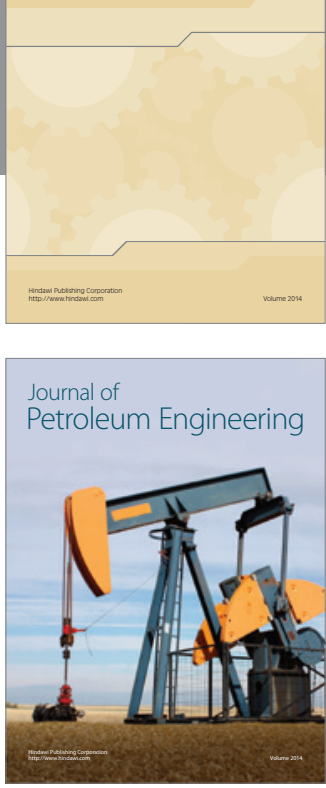

Journal of

Solar Energy
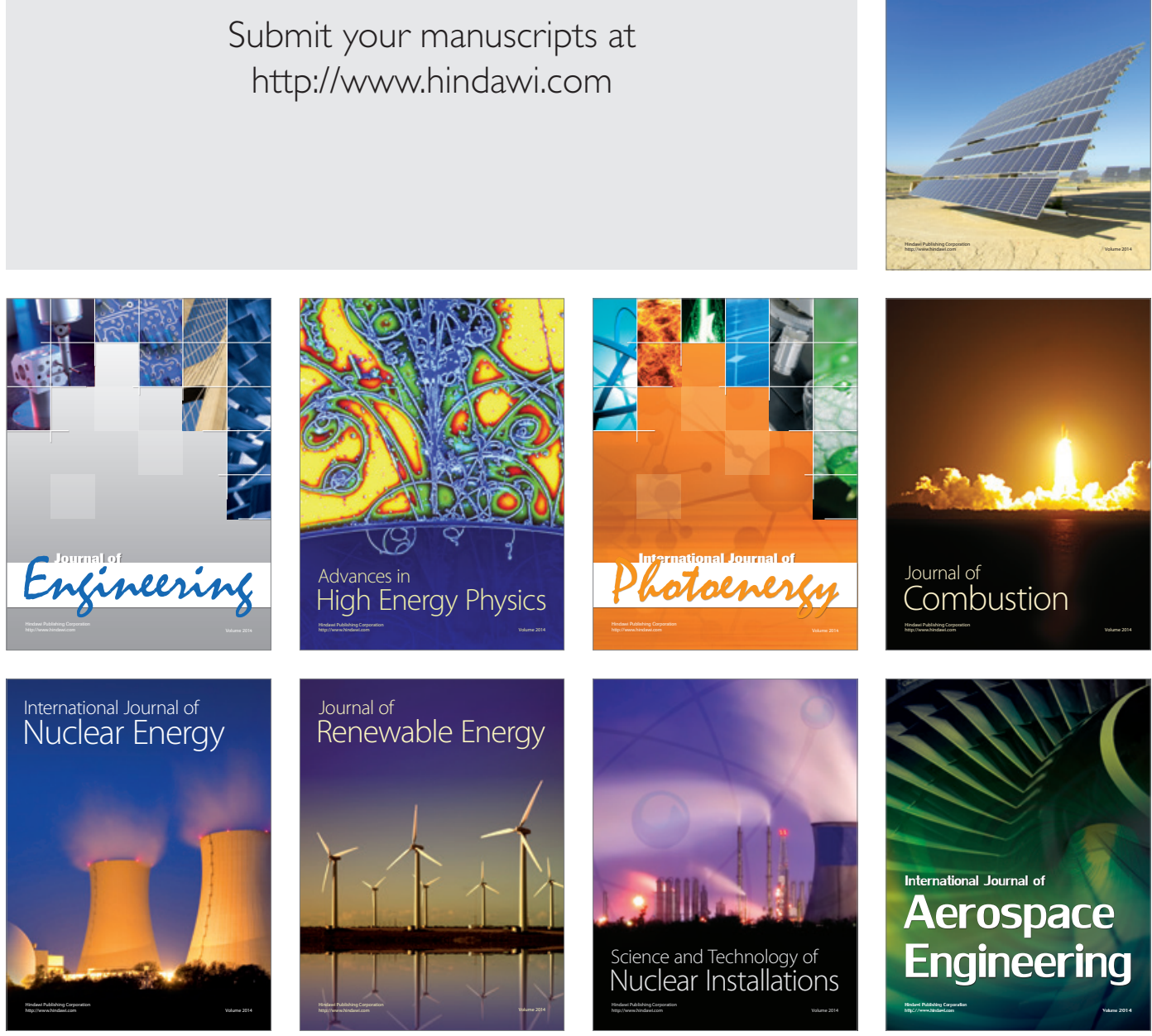